\title{
Comparison of the adhesion of calcium oxalate monohydrate to HK-2 cells before and after repair using tea polysaccharides
}

This article was published in the following Dove Press journal: International Journal of Nanomedicine

\author{
Yao-Wang Zhao' \\ $\mathrm{Da}$ Guo ${ }^{2}$ \\ Chuang-Ye Li ${ }^{1}$ \\ Jian-Ming Ouyang ${ }^{2}$ \\ 'Department of Urology, Hunan \\ Children's Hospital, Changsha 410007, \\ People's Republic of China; ${ }^{2}$ Institute of \\ Biomineralization and Lithiasis Research, \\ Jinan University, Guangzhou 510632, \\ People's Republic of China
}

Background: Kidney stone formation is closely related to renal epithelial cell damage and the adhesion of calcium oxalate crystals to cells.

Methods: In this research, the adhesion of human kidney proximal tubular epithelial cells (HK-2) to calcium oxalate monohydrate crystals with a size of approximately $100 \mathrm{~nm}$ was studied. In addition, the inhibition of crystal adhesion by four tea polysaccharides (TPS0, TPS1, TPS2, and TPS3) with the molecular weights of $10.88,8.16,4.82$, and $2.31 \mathrm{kDa}$, respectively were compared. Results: When oxalic acid-damaged HK-2 cells were repaired, cell viability increased. By contrast, reactive oxygen species level, phosphatidylserine eversion, and osteopontin expression decreased, thus indicating that tea polysaccharides have a repairing effect on damaged HK-2 cells. Moreover, after repairing the damaged cells, the amount of adherent crystals was reduced. The repair effect of tea polysaccharides is closely related to molecular weight, and TPS2 with the moderate molecular weight displayed the best repair effect.

Conclusion: These results suggest that tea polysaccharides, especially TPS2, may inhibit the formation and recurrence of calcium oxalate kidney stones.

Keywords: tea polysaccharide, kidney stone, crystal adhesion, molecular weight

\section{Introduction}

Kidney stones are a kind of global disease. Treatments exist, but the recurrence rate of kidney stones remains high, and no effective prevention methods have been found. $^{1-3}$ The main components of calcium oxalate kidney stones are calcium oxalate monohydrate (COM) and calcium oxalate dihydrate. Specifically, kidney stones are mostly composed of COM. ${ }^{4}$ Crystal retention in renal tubules is a critical step toward kidney stone formation. ${ }^{5}$ The crystals adhere to kidney cells and aggregate to form kidney stones. ${ }^{6}$ When the cells are damaged, the number of adherent crystals is significantly increased, which may be associated with increased expression of adherent molecules, such as hyaluronic acid, ${ }^{7}$ phosphatidylserine (PS), ${ }^{8}$ transmembrane protein, and osteopontin (OPN). ${ }^{9}$ These negatively charged adhesion molecules can adsorb $\mathrm{Ca}^{2+}$ ions in solution and adhere to positively charged COM crystals. When the damaged cells are repaired, the expression of adherent molecules and the number of adherent crystals is reduced. ${ }^{10}$ We previously compared the adhesion and internalization between African green monkey kidney epithelial cells (Vero) and nano-COM crystals $(97 \pm 35 \mathrm{~nm})$ before and after being damaged by hydrogen peroxide. The results showed that the adherent crystals of damaged cells are significantly stronger than normal cells. ${ }^{11}$
Correspondence: Yao-Wang Zhao Department of Urology, Hunan Children's

Republic of China

Tel +8673185356528

Email yw508@sina.com

Jian-Ming Ouyang

Institute of Biomineralization and Lithiasis

Research, Jinan University, Guangzhou

510632, People's Republic of China

Tel +862085223353

Email toyjm@jnu.edu.cn 
Plant polysaccharides not only repair individual organelles in cells ${ }^{12}$ but also reduce the expression of adherent molecules on the cell surface. ${ }^{13}$ For example, degraded soybean polysaccharide can reduce hyaluronic acidexpression on the surface of Vero cells induced by oxidative damage. ${ }^{14}$ On the surface of normal Madin-Darby canine kidney (MDCK), the adhesion of COM is $0.2 \pm 0.03 \mu \mathrm{g} / \mathrm{cm}^{2}$, and the adhesion of cells after being injured increases to $2.33 \pm 0.26 \mu \mathrm{g} / \mathrm{cm}^{2}$. When the damaged cells are selfrepaired, the adhesion reduces to $0.16 \pm 0.02 \mu \mathrm{g} / \mathrm{cm}^{2-10}$

In recent years, tea polysaccharides have attracted attention due to their wide range of biological activities. Tea polysaccharides have anti-oxidation, anticancer, and anti-radiation properties. Moreover, they can lessen blood sugar levels and regulate immunity. ${ }^{15-17}$ For example, selenium-containing tea polysaccharides increase the ratio of $\mathrm{Bax} / \mathrm{Bcl}-2$, increase the activation of caspase- 3 and caspase-9, and inhibit the proliferation of human breast cancer cells (MCF-7) by triggering the mitochondrial apoptotic pathway. ${ }^{18}$ Gao et $\mathrm{al}^{19}$ and Park et $\mathrm{al}^{20}$ had similar findings. ${ }^{19-20}$ Additionally, ziyang tea polysaccharide has a protective effect on liver injury induced by $\mathrm{CCl}_{4}$ in mice. ${ }^{21}$ Glyphosate inhibits proliferation of mouse testicular cells, increases malondialdehyde and dehydrogenase levels, and reduces the activation of superoxide dismutase. On the contrary, tea polysaccharides can inhibit these effects and repair damaged cells. ${ }^{22}$ Ilex Kuding tea polysaccharide has a repairing effect on high fructose-induced liver injury and endothelial dysfunction in mice. ${ }^{23}$ Exposure of vascular endothelial cells to high glucose $(33 \mathrm{mM})$ for 12 $h$ leads to a significant decrease by $30 \%$ versus normal control in cell viability. By contrast, conjugates of green tea polysaccharide increase cell viability in a concentration-dependent manner. ${ }^{24}$

Our previous study revealed that four degraded tea polysaccharides (TPS0, TPS1, TPS2, and TPS3) with molecular weight of $10.88,8.16,4.82$, and $2.31 \mathrm{kDa}$, respectively, can improve cell morphology and repair the lysosomes and cell membranes of damaged HK-2 cells. In this research, the differences in COM crystal adhesion to HK-2 cells before and after repair with tea polysaccharides are further investigated. Furthermore, we aimed to provide new insights into the possible utilization of tea polysaccharides for prophylaxis and to explore their therapeutic potential in treating kidney stones as a candidate drug in different dosage forms.

\section{Experimental method}

\section{Reagents and instruments}

Tea polysaccharide (TPS0) was provided by Shaanxi Ciyuan Biological Co., Ltd. and its molecular weight was $10.88 \mathrm{kDa}$. The degradation of polysaccharides was performed as previously described. ${ }^{25}$ The molecular weight of TPS1, TPS2, and TPS3 was $8.16,4.82$, and $2.31 \mathrm{kDa}$, respectively.

COM was synthesized according to a previous study. ${ }^{26}$ Scanning electron microscopy (SEM) and X-ray powder diffraction indicate that it is a target crystal with a size of about $100 \mathrm{~nm}$.

Human kidney proximal tubular epithelial (HK-2) cells were purchased from Shanghai Cell Bank, Chinese Academy of Sciences (Shanghai, People's Republic of China). FBS and cell culture medium (DMEM-F12) were purchased from HyClone Biochemical Products Co. Ltd. (Beijing, People's Republic of China). The cell proliferation assay kit (Cell Counting Kit-8 (CCK-8)) was purchased from Dojindo Laboratory (Kumamoto, Japan). The Reactive Oxygen Detection Kit $\left(2^{\prime}, 7^{\prime}\right.$-dichlorofluorescein diacetate), rabbit anti-mouse IgG conjugated with fluorescein isothiocyanate (FITC-IgG), and Annexin V-FITC were all purchased from Shanghai Beyotime Bio-Tech Co., Ltd. (Shanghai, People's Republic of China). Paraformaldehyde and ethanol were of analytical grade (Guangzhou Chemical Reagent Factory).

The apparatus included an ultraviolet-visible spectrophotometer (Cary 500; Varian, USA), a microplate reader (SafireZ; Tecan, Switzerland), a flow cytometer (FACS Aria; BD, Franklin Lakes, NJ, USA), a field emission scanning electron microscope (ULTRA 55; Carl Zeiss Meditec AG, Jena, Germany), an optical microscope (CKX41; Olympus Corporation, Tokyo, Japan), a multifunction microplate detector (SYNERGY H1M; BioTek, USA), and a laser confocal microscope (LSM510 META DuoScan; Carl Zeiss Meditec AG).

\section{Cell culture}

HK-2 cells were cultured in a DMEM-F12 culture medium containing $10 \%$ FBS and $100 \mathrm{U} / \mathrm{mL}$ penicillin- 100 and $\mu \mathrm{g} / \mathrm{mL}$ streptomycin antibiotics with $\mathrm{pH} 7.4$ at $37{ }^{\circ} \mathrm{C}$ in a $5 \% \mathrm{CO}_{2}$ humidified environment. Upon reaching an $80-90 \%$ confluent monolayer, cells were blown gently after trypsin digestion to form a cell suspension for the following cell experiments.

\section{Cell viability detection by CCK-8}

Cell suspension with a cell concentration of $1 \times 10^{5}$ cells $/ \mathrm{mL}$ was inoculated per well in 96-well plates and incubated in 
DMEM-F12 culture medium for $24 \mathrm{~h}$. The cells were divided into three groups: 1) normal control group, in which only serum-free culture medium was added; 2) damage control group, in which serum-free culture medium with $2.8 \mathrm{mM}$ oxalate was added and incubated for $3.5 \mathrm{~h}$; and 3) repair group, in which the serum-free medium containing $80 \mu \mathrm{g} / \mathrm{mL}$ TPS0, TPS1, TPS2, and TPS3 was added to repair the damaged cells and incubated for $10 \mathrm{~h}$. After reaching the time, $10 \mu \mathrm{L}$ of $\mathrm{CCK}-8$ reagent was added to each well and incubated for $4 \mathrm{~h}$. The OD values were measured using the enzyme mark instrument at $450 \mathrm{~nm}$ to detect the repair capacity of polysaccharide.

\section{Reactive oxygen species (ROS) detection}

Two milliliters of cell suspension with a cell concentration of $1 \times 10^{5}$ cells $/ \mathrm{mL}$ was inoculated per well in 6 -well plates. Following the cell incubations described in Section 2.3, the cells were digested and centrifuged at $1000 \mathrm{rpm}$ for 5 min. The cells were resuspended by adding and thoroughly mixing $500 \mu \mathrm{L}$ of PBS in a microcentrifuge tube. The samples were then stained with $2^{\prime}, 7^{\prime}$-dichlorofluorescein diacetate and analyzed by flow cytometry.

\section{PS eversion detection}

Two milliliters of cell suspension with a cell concentration of $1 \times 10^{5}$ cells $/ \mathrm{mL}$ was inoculated per well in 6 -well plates. Following the cell incubations described in Section 2.3, the culture medium was aspirated, washed twice with PBS, then $100 \mu \mathrm{L}$ of Binding Buffer and $10 \mu \mathrm{L}$ FITC-labeled Annexin- $\mathrm{V}$ were added, and the cells were kept in the dark for $30 \mathrm{~min}$ at room temperature. After treatment, the cells were detected by flow cytometry.

\section{OPN expression detection}

Two milliliters of cell suspension with a cell concentration of $1 \times 10^{5}$ cells $/ \mathrm{mL}$ was inoculated per well in 6 -well plates. Following the cell incubations described in Section 2.3, the supernatant was aspirated and the cells were washed three times with PBS. Then, 4\% paraformaldehyde was added to fix the cells for $10 \mathrm{~min}$. Subsequently, the cells were washed with PBS three times. The sheep serum was added to incubate cells for $20 \mathrm{~min}$. The first antibody of OPN was dropped into this sample (1:100) (Santa Cruz Biotechnology Inc., Dallas, TX, USA) and was laid still overnight at $4{ }^{\circ} \mathrm{C}$. After this, the cells were rinsed three times with PBS before the addition of FITC secondary antibody (1:100) (Santa Cruz Biotechnology Inc.) in the dark. The cells were rinsed three times with PBS again after incubation for $0.5 \mathrm{~h}$ at $37{ }^{\circ} \mathrm{C}$. Finally, the cells were stained with DAPI. The fluorescence was observed using a laser confocal fluorescence microscope. The color of the nucleus was blue, the OPN was green.

For quantitative detection of OPN, referring to the above method, a 96-well plate was used to quantitatively detect the fluorescence intensity by a multifunctional microplate reader.

\section{Observation of crystal adhesion on the cell surface by SEM}

The suspension cells were inoculated into 12-well plates covered with coverslips at a cell concentration of $1 \times 10^{5}$ cells/mL, with $1 \mathrm{~mL}$ per well. Following the cell incubations described in Section 2.3, the cells were washed twice with D-Hanks solution. A serum-free medium containing $200 \mu \mathrm{g} /$ $\mathrm{mL}$ COM was added to cells. After $1 \mathrm{~h}$ of incubation, the supernatant was aspirated. After washing the cells twice with PBS, 2.5\% glutaraldehyde was added for $24 \mathrm{~h}$ and then washed three times with PBS. The cells were dehydrated by graded ethanol $(30 \%, 50 \%, 70 \%, 90 \%$, and 100\%), dried at the critical point of $\mathrm{CO}_{2}$, and sprayed with gold. After processing the sample, crystal adhesion was observed by SEM.

\section{Fluorescent labeling of COM crystals}

Preparation of FITC-IgG fluorescent-labeled crystals was performed as described previously. ${ }^{27}$ The well-weighed crystals were pelleted, sterilized by ultraviolet radiation for $40 \mathrm{~min}$, prepared by adding $400 \mu \mathrm{g} / \mathrm{mL}$ solution with serum-free medium, and sonicated for $5 \mathrm{~min}$. A total of 10 $\mu$ L FITC-labeled anti-rat $\operatorname{IgG}(1 \mathrm{mg} / \mathrm{mL})$ was added to the 4-mL DMEM-F12 solution with $400 \mu \mathrm{g} / \mathrm{mL}$ COM and incubated overnight at room temperature in the dark. Unreacted free FITC-IgG was dialyzed using a dialysis bag (Mw 8000-14,000). Afterward, the DMEM-F12 solution was removed by centrifugation, washed twice with PBS, dried by centrifugation, and stored. The FITC-IgGlabeled crystals were resuspended in anhydrous ethanol, sonicated for $10 \mathrm{~min}$, placed on glass slides, air-dried, and observed under a fluorescence microscope.

\section{Qualitative observation of crystal adhesion on cells}

Two milliliters of cell suspension with a cell concentration of $1 \times 10^{5}$ cells $/ \mathrm{mL}$ was inoculated per well in 6 -well plates. Afterward, the cells were transferred to a $4{ }^{\circ} \mathrm{C}$ environment for cultivation for $30 \mathrm{~min}$ to inhibit the endocytic activity of cells. Crystals can only adhere to cells at $4{ }^{\circ} \mathrm{C}$. 
The experimental model is the same as described in Section 2.3 . A total of $200 \mu \mathrm{g} / \mathrm{mL}$ freshly prepared green fluorescence-labeled COM was added to the cells after the repair using tea polysaccharides, and the cells were transferred to $4{ }^{\circ} \mathrm{C}$ for $1 \mathrm{~h}$. After reaching the culture time, the culture medium was aspirated and washed twice with cold PBS to remove the unattached and nontightly adherent crystals. Afterward, cells were stained with $300 \mu \mathrm{L}$ DiI for $10 \mathrm{~min}$, and the nuclei were stained with DAPI and fixed with $4 \%$ paraformaldehyde for $10 \mathrm{~min}$. The state of crystal adhesion on cells was observed under a laser scanning confocal microscope.

\section{Quantitative analysis of the percentage of cells adhered by crystals by flow cytometry}

Two milliliters of cell suspension with a cell concentration of $1 \times 10^{5}$ cells $/ \mathrm{mL}$ was inoculated per well in 6-well plates for $24 \mathrm{~h}$. After cooling at $4{ }^{\circ} \mathrm{C}$ for $30 \mathrm{~min}$, the medium was then aspirated and washed twice with cold PBS. The experimental models were divided into four groups: 1) blank control group, serum-free medium was added; 2) normal control group, $200 \mu \mathrm{g} / \mathrm{mL}$ freshly prepared green fluorescence-labeled COM was added to normal HK-2 cells; 3) damage control group, HK-2 cells after oxalic acid injury were added with $200 \mu \mathrm{g} / \mathrm{mL}$ freshly prepared green fluorescence-labeled COM; and 4) repair group, 200 $\mu \mathrm{g} / \mathrm{mL}$ freshly prepared green fluorescence-labeled COM was added to the cells after repair using tea polysaccharides, and four groups of cells were transferred to $4{ }^{\circ} \mathrm{C}$ for 1 h. After reaching the culture time, the culture medium was aspirated and washed twice with cold PBS to remove the unattached and nontightly adherent crystals. After digesting trypsin, the cells were resuspended in PBS, and the average fluorescence intensity and adherence were measured by flow cytometer. Cells with a FITC signal can be regarded as cells with adherent crystals.

\section{Statistical analysis}

Experimental data were expressed as mean \pm SD from at least three independent experiments. The experimental results were statistically analyzed using SPSS 13.0 software and the Tukey test was used to analyze the differences between the mean of each experimental group and control group. If $p<0.05$, there was a significant difference; if $p<0.01$, the difference was extremely significant; if $p>0.05$, there was no significant difference.

\section{Experimental results}

\section{Cell viability before and after repair}

Figure 1 shows the cell viability of HK-2 cells before and after tea polysaccharide repair. Cell viability significantly decreased after oxalic acid oxidative damage (51.47\%), which was about half that of the normal group (100.0\%). The cell viability of each repair group significantly increased. Cell viability after repair by TPS0, TPS1, TPS2, and TPS3 was $61.59 \%, 81.83 \%, 91.26 \%$, and $77.50 \%$, respectively, and the repair ability of TPS2 with moderate molecular weight was the strongest.

\section{ROS levels of HK-2 cells before and after repair}

Figure 2A illustrates the ROS levels of HK-2 cells before and after tea polysaccharide repair. The average fluorescence intensity of ROS in the injury group (7826) was significantly higher than that in the normal group (3928), whereas the ROS intensity in the repair groups (7022-4684) was between that in the normal and injury groups (Figure 2B). Moreover, the ROS intensity of the TPS2 repair group was the weakest, indicating that TPS2 had the strongest repair ability.

\section{PS eversion of HK-2 cells before and after repair}

PS is an important adhesion molecule that promotes crystalcell adhesion. ${ }^{28}$ Normally, PS is inside the tubular epithelial cell membrane, but when the cell is damaged, PS flips to the surface. ${ }^{29}$ Figure $3 \mathrm{~A}$ displays the PS eversion of HK-2 cells before and after tea polysaccharide repair. In the normal group, PS eversion was small (5.41\%), whereas in the injury group it

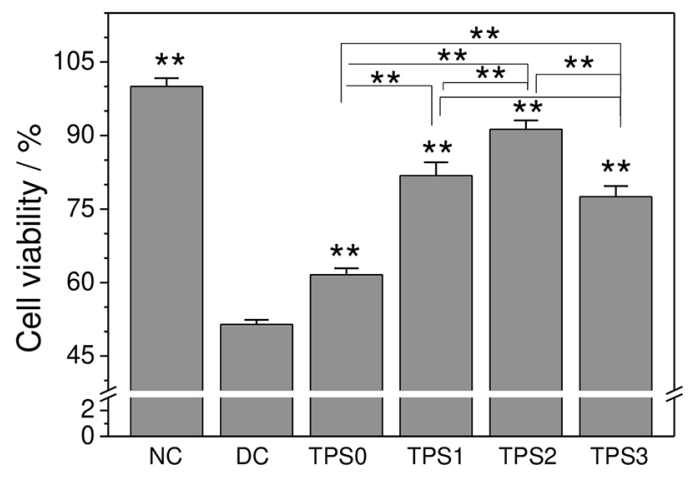

Figure I Cell viability of HK-2 cells before and after TPS repair. Oxalate damage concentration: $2.8 \mathrm{mM}$; damage time: $3.5 \mathrm{~h}$; polysaccharide concentration: $80 \mu \mathrm{g} /$ $\mathrm{mL}$; repair time: $10 \mathrm{~h}$. Compared with the DC group: $*_{p}<0.05 ; * *<0.01$.

Abbreviations: DC, damaged control; HK-2, human kidney proximal tubular epithelial; NC, normal control; TPS, tea polysaccharide. 

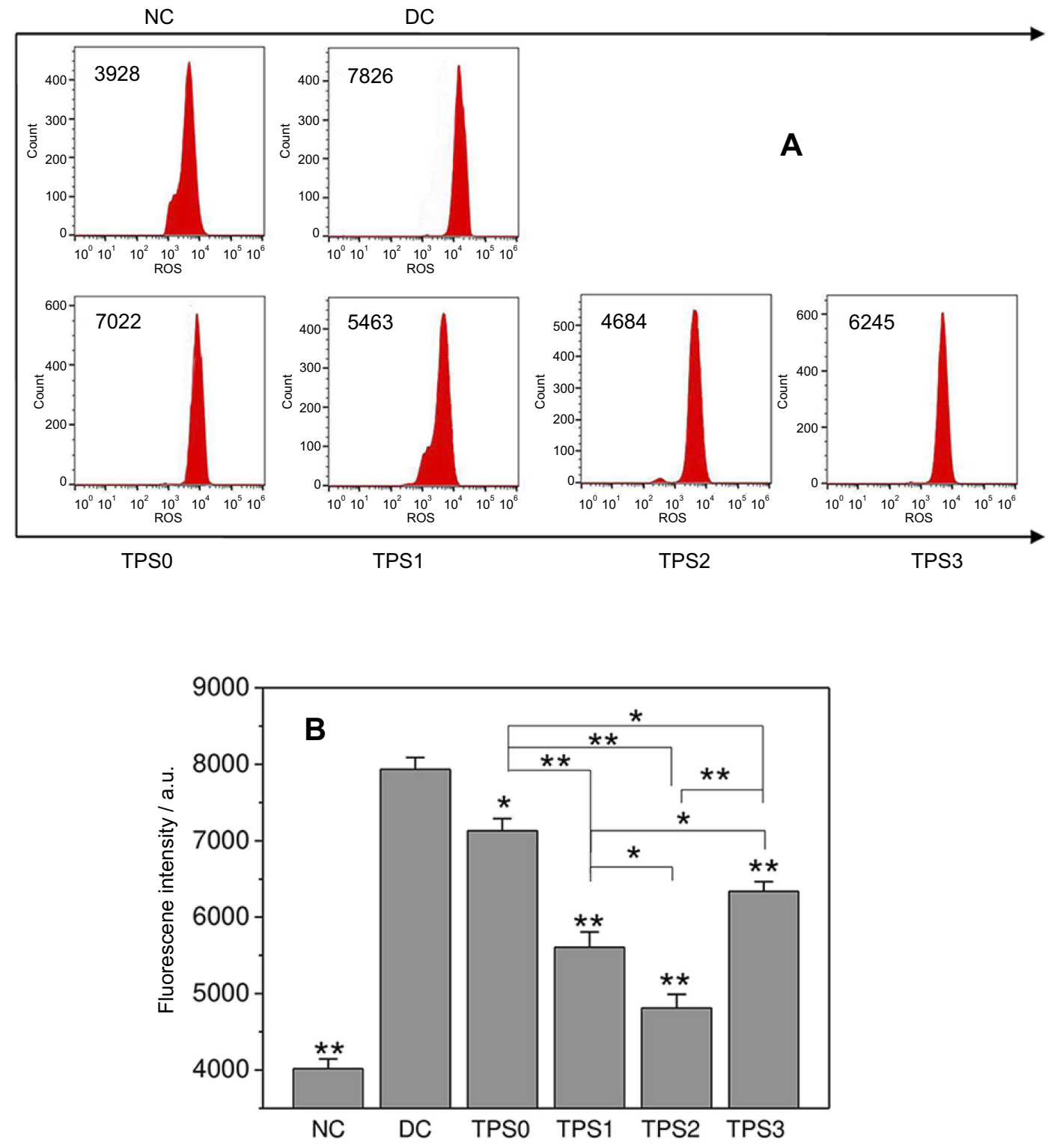

Figure 2 ROS levels of HK-2 cells before and after TPS repair by flow cytometry detection. (A) Histogram of ROS levels. (B) Statistical histogram of ROS levels. Oxalate damage concentration: $2.8 \mathrm{mM}$; damage time: $3.5 \mathrm{~h}$; polysaccharide concentration: $80 \mu \mathrm{g} / \mathrm{mL}$; repair time: $10 \mathrm{~h}$. Compared with the DC group: ${ }^{*} p<0.05$; $* *<<0.0$ I.

Abbreviations: DC, damaged control; HK-2, human kidney proximal tubular epithelial; NC, normal control; ROS, reactive oxygen species; TPS, tea polysaccharide.

significantly increased (22.12\%). After repairing injured cells with TPS0, TPS1, TPS2, and TPS3, PS eversion decreased to a certain extent (7.24-13.01\%), and the decrease in the TPS2 group was the most significant (7.24\%) (Figure 3B). After reducing the PS eversion on the cell surface, the adhesion of COM crystals to cells was effectively reduced.

\section{OPN expression of HK-2 cells before and after repair}

OPN with a molecular weight of $60-80 \mathrm{kDa}$ is a phosphorylated glycoprotein rich in sialic acid. Cell damage leads to an increase in OPN expression. ${ }^{30}$ Figure 4 demonstrates the OPN expression on the HK-2 cell surface before and after tea polysaccharide repair. The OPN green color of the normal group was not evident, indicating that OPN expression was low. However, OPN expression on the cell surface of the injury group increased (Figure. 4A and B).

\section{SEM observation of crystal adhesion on the cell surface}

Figure 5 shows the adhesion of HK-2 cells to COM with a size of approximately $100 \mathrm{~nm}$ before and after tea polysaccharide repair observed by SEM. The cells in the normal group were full-bodied and fusiform, with a few adhered 

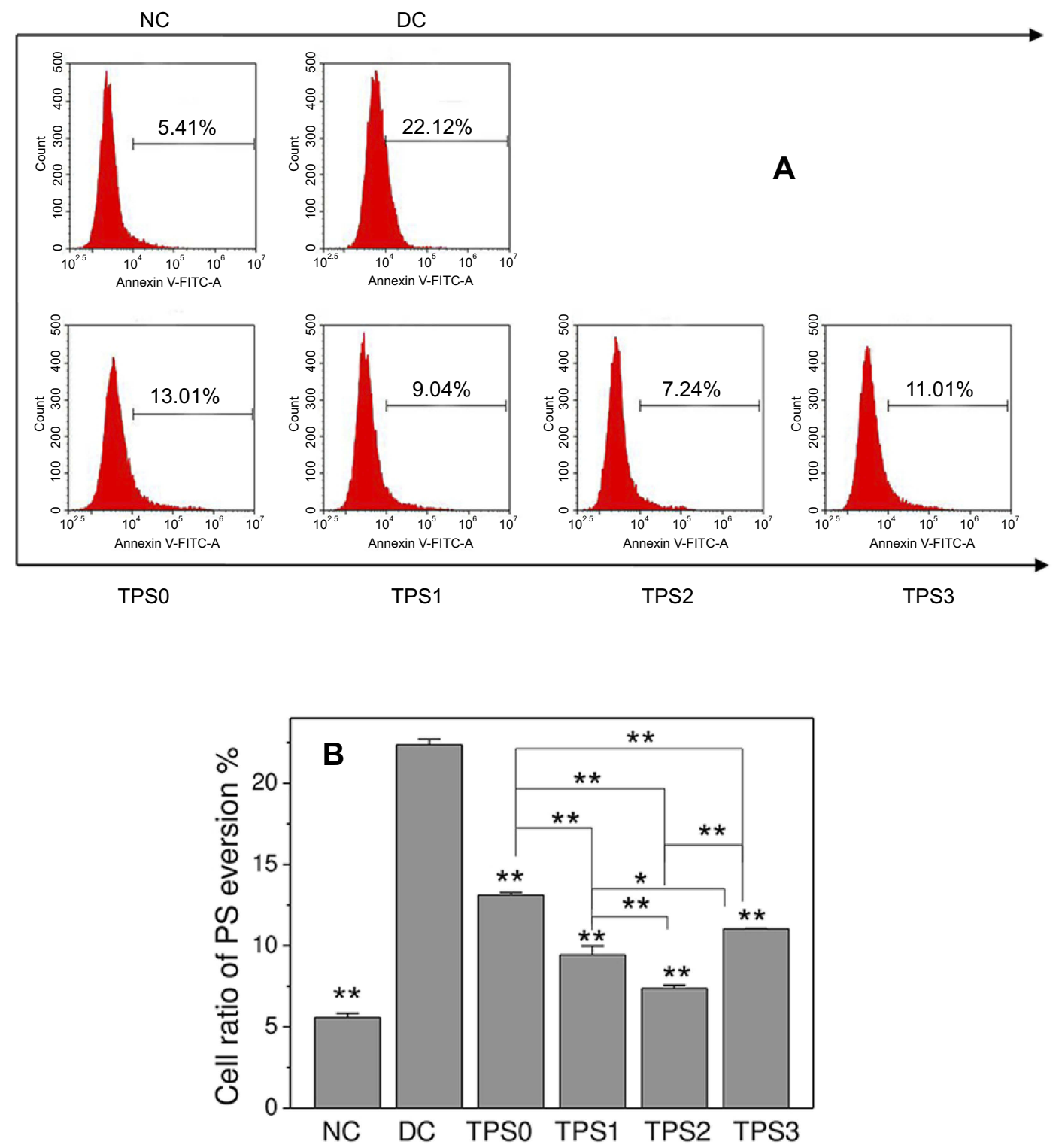

Figure 3 PS eversion of HK-2 cells before and after TPS repair by flow cytometry. (A) Histogram of PS eversion ratio. (B) Statistical histogram of the percentage of PS eversion. Oxalate damage concentration: $2.8 \mathrm{mM}$; damage time: $3.5 \mathrm{~h}$; polysaccharide concentration: $80 \mu \mathrm{g} / \mathrm{mL}$; repair time: $10 \mathrm{~h}$. Compared with the DC group: $* p<0.05$; $* * 00.01$.

Abbreviations: DC, damaged control; FITC, fluorescein isothiocyanate; HK-2, human kidney proximal tubular epithelial; NC, normal control; PS, phosphatidylserine; ROS, reactive oxygen species; TPS, tea polysaccharide.

crystals. The cell morphology of the injury group obviously changed, the cells contracted, and the number of adherent crystals obviously increased. The cell morphology of the repair group gradually recovered to that of normal cells, and the number of adherent crystals was between that of the normal and injury groups. However, no significant difference was found among the repair groups in SEM images.

\section{Qualitative observation of crystal adhesion to the cell}

Crystal adhesion to the cell surface was further observed by FITC-IgG fluorescently labeling nano-COM crystals. Plain
COM crystals can be labeled with FITC-IgG. The crystal morphology before and after labeling did not change (Figure 6A and B). The FITC characteristic absorption peak was observed, and the absorption intensity was determined (Figure 6C). Green fluorescence was observed under an inverted fluorescence microscope (Figure 6B), and more than $99 \%$ of COM crystals were labeled (Figure $6 \mathrm{E}$ and F). Therefore, adhesion experiments were performed by fluorescently labeled crystals, and cells with FITC signals were considered to have adherent crystals.

Figure 7 illustrates nano-COM adhesion to HK-2 cells before and after tea polysaccharide repair by 

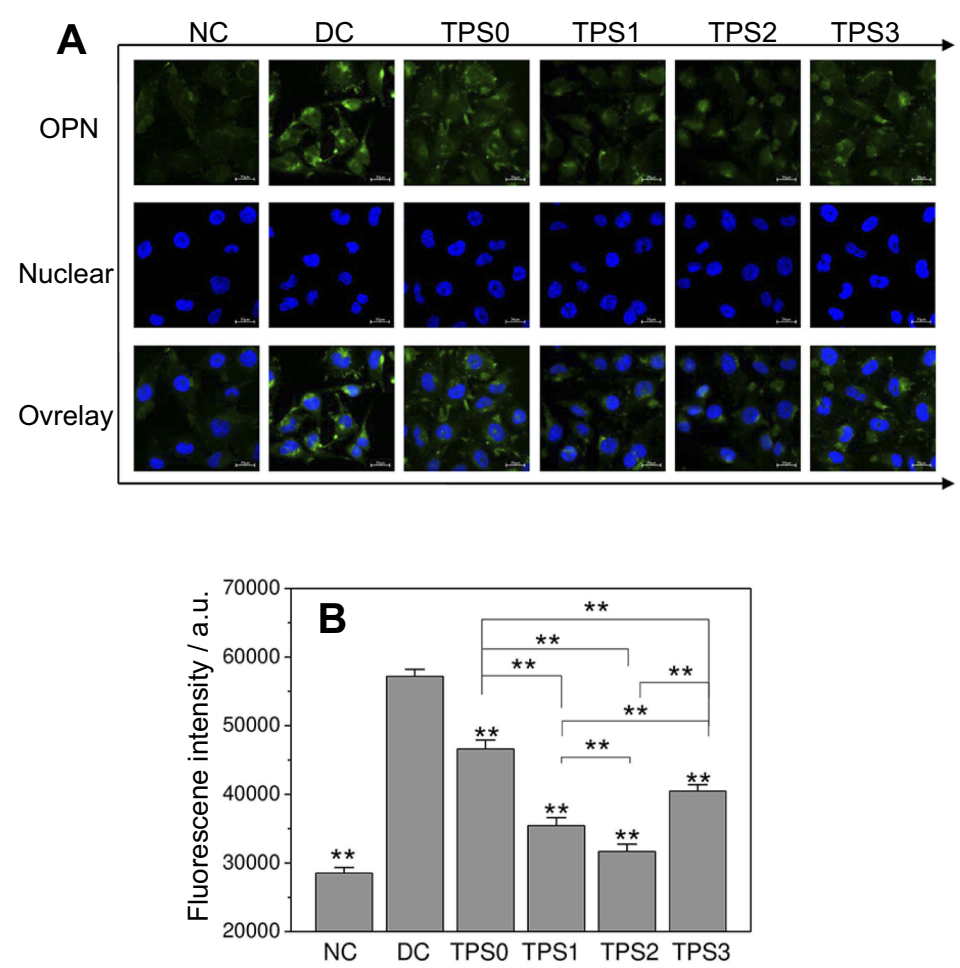

Figure 4 OPN expression on the HK-2 cell surface before and after TPS repair. (A) Fluorescence observation of OPN expression. (B) Statistical histogram of OPN expression. Oxalate damage concentration: $2.8 \mathrm{mM}$; damage time: $3.5 \mathrm{~h}$; polysaccharide concentration: $80 \mu \mathrm{g} / \mathrm{mL}$; repair time: $10 \mathrm{~h}$. Compared with the DC group: **p<0.0I. Abbreviations: DC, damaged control; HK-2, human kidney proximal tubular epithelial; NC, normal control; OPN, osteopontin; TPS, tea polysaccharide.

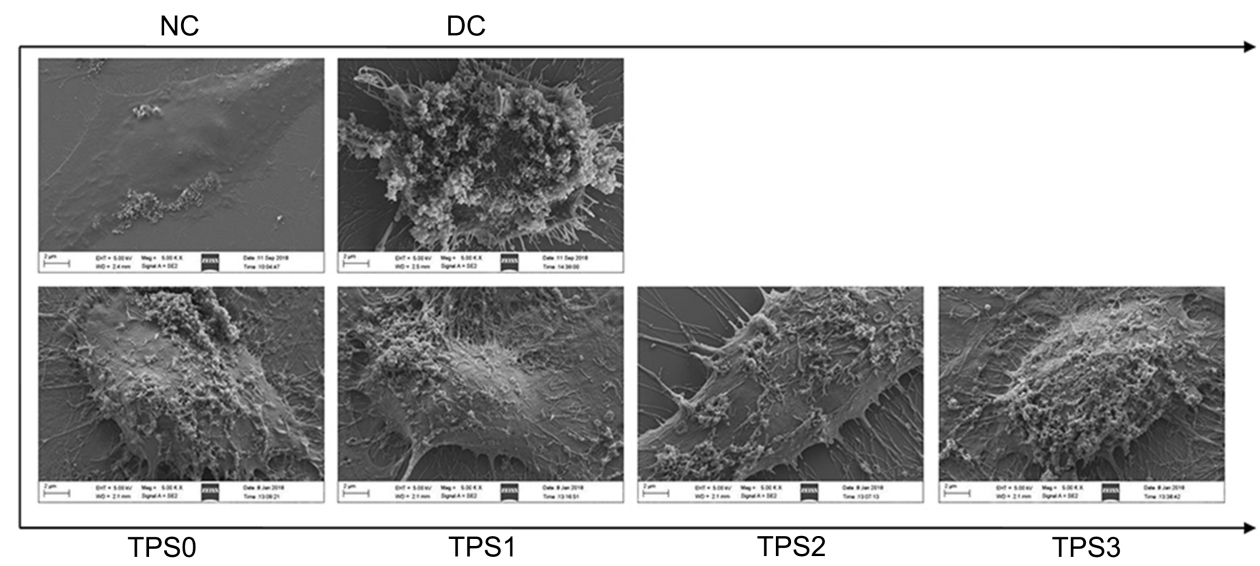

Figure 5 The adhesion of HK-2 cells to COM with a size of approximately $100 \mathrm{~nm}$ before and after TPS repair observed by scanning electron microscopy. Oxalate damage concentration: $2.8 \mathrm{mM}$; damage time: $3.5 \mathrm{~h}$; polysaccharide concentration: $80 \mu \mathrm{g} / \mathrm{mL}$; repair time: $10 \mathrm{~h}$; COM concentration: $200 \mu \mathrm{g} / \mathrm{mL}$; adherent time: I h.

Abbreviations: COM, calcium oxalate monohydrate; DC, damaged control; HK-2, human kidney proximal tubular epithelial; NC, normal control; TPS, tea polysaccharide.

confocal microscopy. The number of crystals adhered to damaged cells was obviously increased compared with normal cells, and the crystals likely aggregated. After repairing cells with tea polysaccharides of different molecular weights, the number of adhered crystals was reduced.
In addition, morphological changes of cells before and after repair were simultaneously observed. The nucleus of the normal group was intact and round, and the chromatin was evenly distributed. The damaged cell nucleus shrank, and the chromatin was concentrated. The shape of the repaired nucleus mostly returned to 


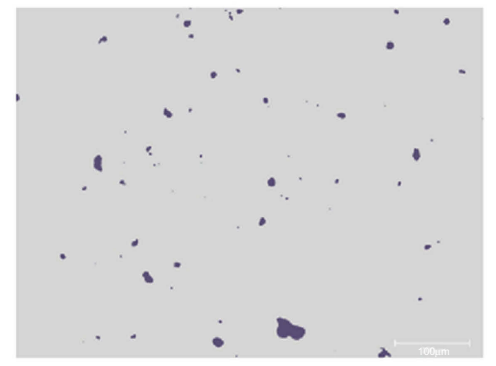

A

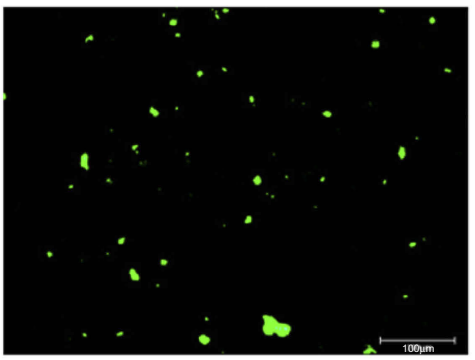

B

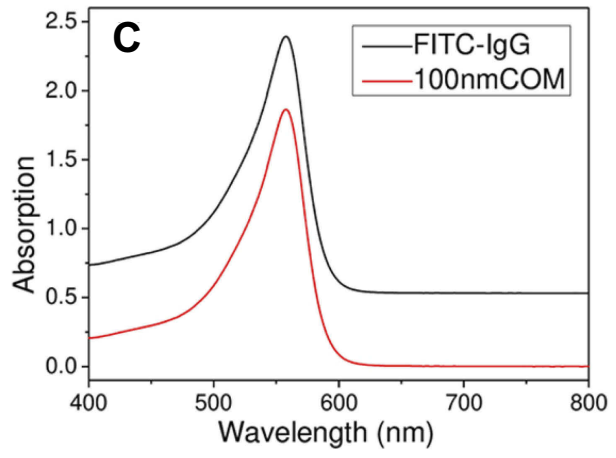

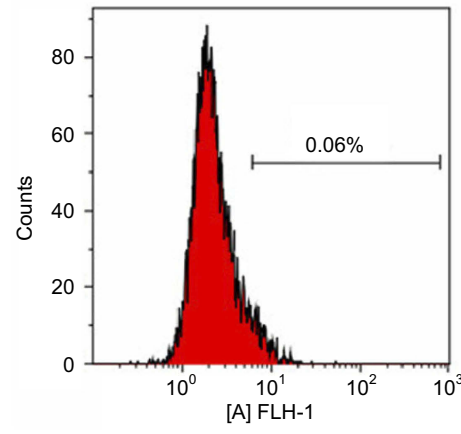

D

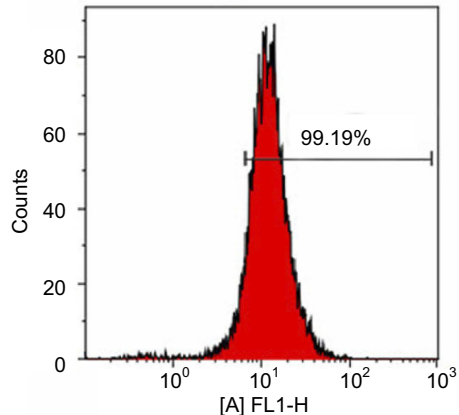

$\mathbf{E}$

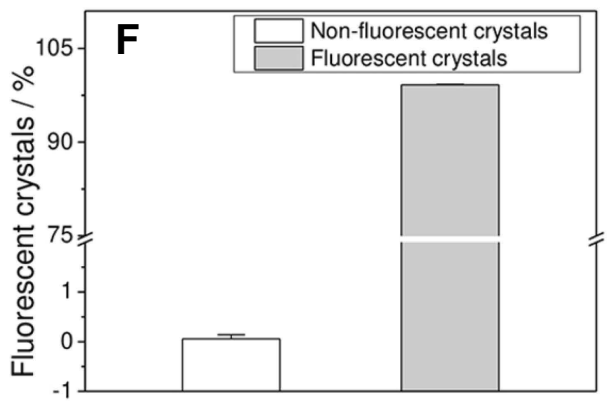

Figure 6 FITC-lgG fluorescent labeling of nano-COM crystals. (A, B) COM crystal images before and after labeling. (C) Ultraviolet-visible absorption spectra of FITC-lgG and its labeled COM solution. (D, E) Flow cytometric analysis histogram of the fluorescent ratio of plain and FITC-lgG fluorescent labeled nano-COM crystals. (F) Fluorescent COM crystal percentage statistics histogram.

Abbreviations: COM, calcium oxalate monohydrate; FITC, fluorescein isothiocyanate. 


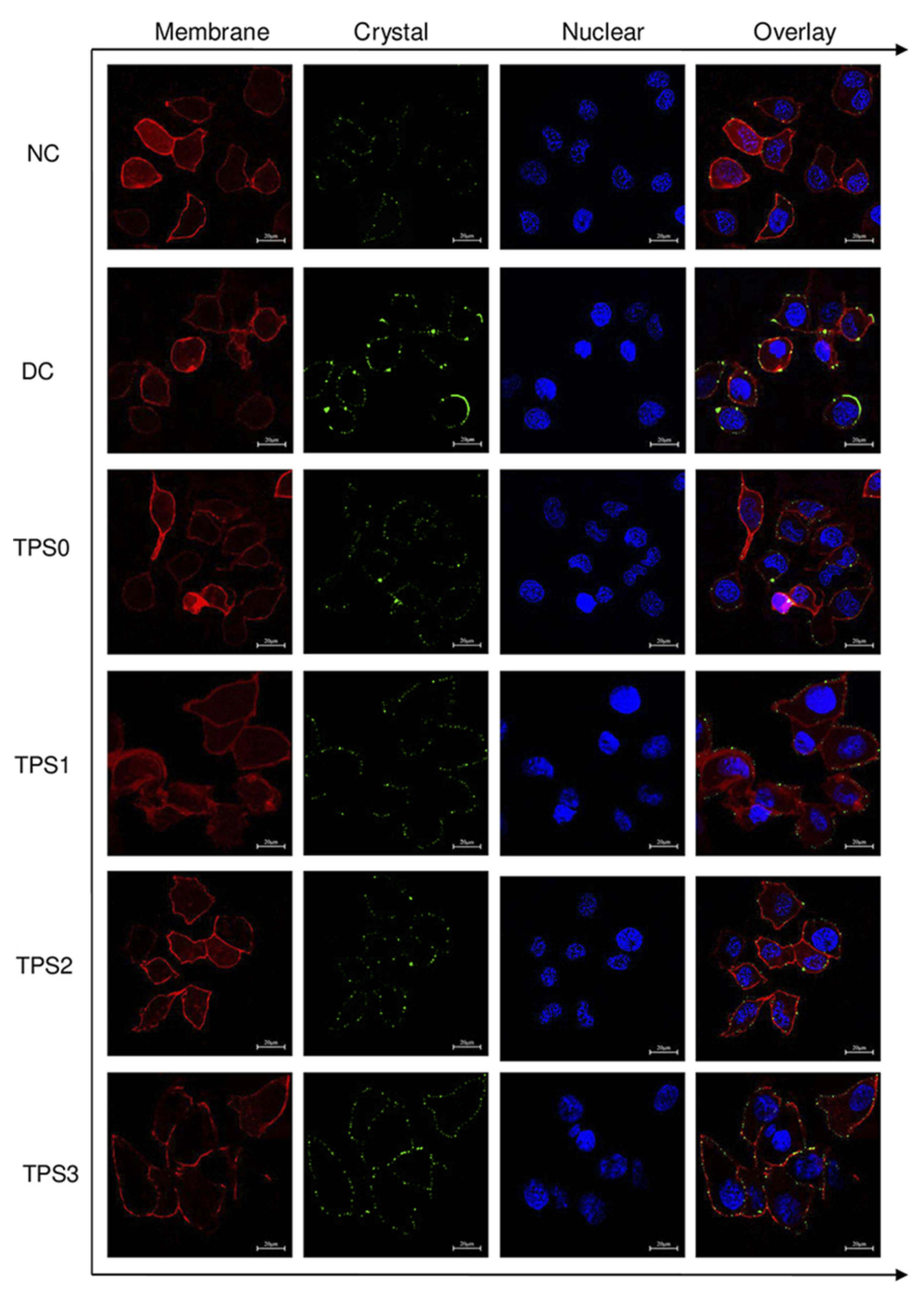

Figure 7 Nano-COM adhesion to HK-2 cells before and after TPS repair by confocal microscopy. Oxalate damage concentration: 2.8 mM; damage time: 3.5 h; polysaccharide concentration: $80 \mu \mathrm{g} / \mathrm{mL}$; repair time: $10 \mathrm{~h}$; COM concentration: $200 \mu \mathrm{g} / \mathrm{mL}$; adherent time: I h.

Abbreviations: COM, calcium oxalate monohydrate; DC, damaged control; HK-2, human kidney proximal tubular epithelial; NC, normal control; TPS, tea polysaccharide.

normal, and the nucleus shape of the TPS2 repair group was close to that of the normal group.

\section{Quantitative detection of the proportion of cells adhering to crystals}

The percentage of HK-2 cells adhering to nano-COM before and after tea polysaccharide repair was quantitatively detected by flow cytometry, as shown in Figure 8 . Fluorescent cells $(0.26 \%)$ were almost undetectable in the blank group without crystals. On the contrary, fluorescent cells were detected in other crystal groups (29.3-61.6\%), indicating that the FITC staining of the crystals was successful.

The percentage of cells adhering to the cells in the injury group $(61.6 \%)$ was significantly higher than that in the normal group (29.3\%) (Figure 8B). The percentage of cells adhering to the crystals in the repair group (33.3-50.3\%) was between that of the normal and injury groups. The crystal adhesion of each group was damage control $>$ TPS $0>$ TPS $3>$ TPS $1>$ TPS $2>$ normal control, indicating that the damaged cells after TPS 2 repair had the strongest anti-crystal adhesion ability. 

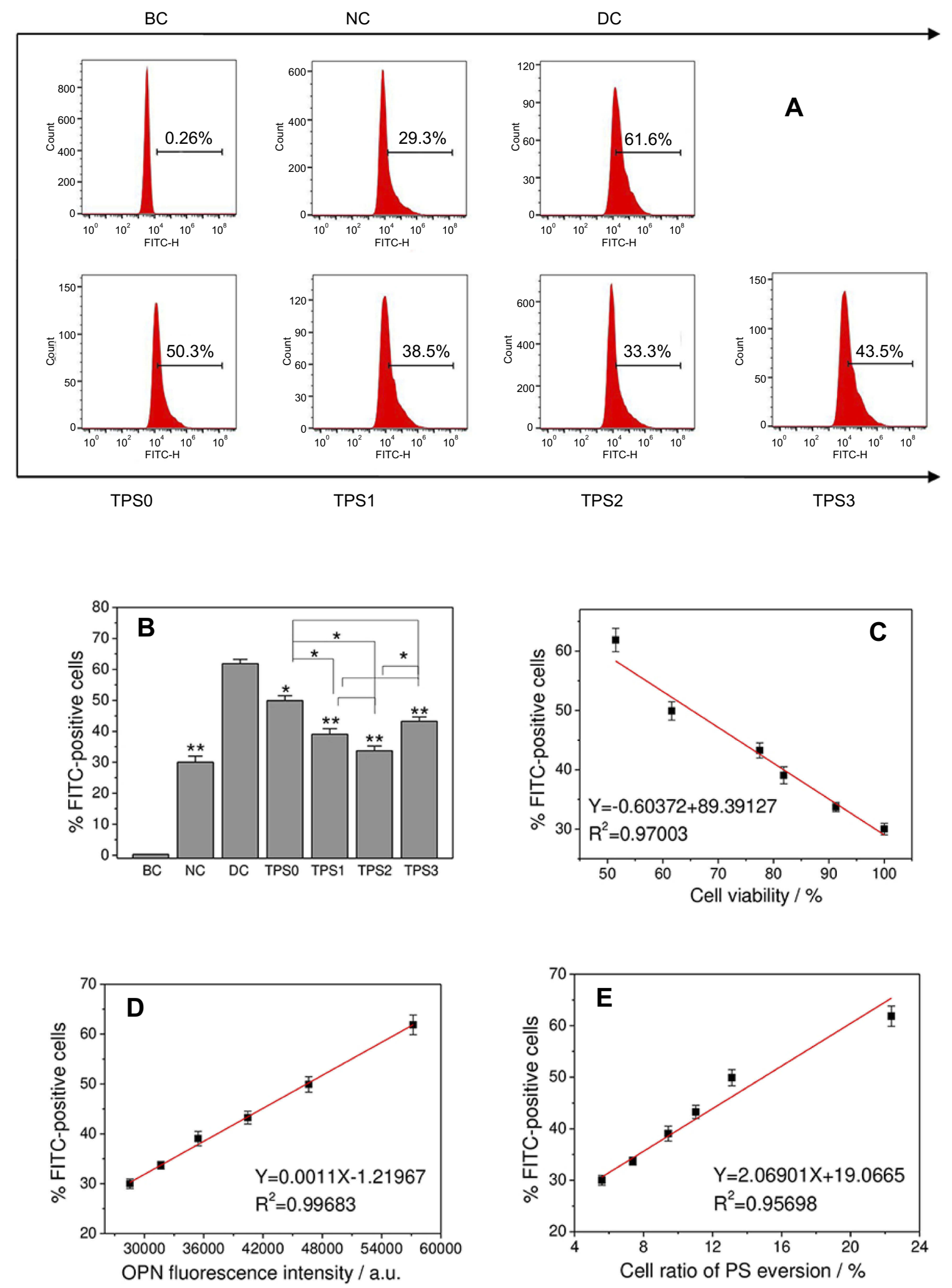

Figure 8 Quantitative detection of the percentage of HK-2 cells adhering to nano-COM before and after TPS repair by flow cytometry. (A) Histogram of the proportion of cells with adhered COM crystals. (B) Statistical histogram of the proportion of cells with adhered COM crystals. (C) The linear relationship of percentage of cells adhering to nano-COM crystals and cell viability. (D) The linear relationship of percentage of cells adhering to nano-COM crystals and OPN expression. (E) The linear relationship of percentage of cells adhering to nano-COM crystals and PS eversion. Oxalate damage concentration: $2.8 \mathrm{mM}$; damage time: $3.5 \mathrm{~h}$; polysaccharide concentration: $80 \mu \mathrm{g} / \mathrm{mL}$; repair time: $10 \mathrm{~h}$; COM concentration: $200 \mu \mathrm{g} / \mathrm{mL}$; adherent time: I h. Compared with DC group: *p<0.05; **p<0.0I.

Abbreviations: BC, blank control; COM, calcium oxalate monohydrate; DC, damaged control; FITC, fluorescein isothiocyanate; HK-2, human kidney proximal tubular epithelial; NC, normal control; OPN, osteopontin; PS, phosphatidylserine; TPS, tea polysaccharide. 


\section{Discussion}

\section{Cell injury by oxalic acid and kidney stone formation}

Numerous studies have shown that $\mathrm{CaOx}$ crystals in acute hyperoxaluria originate from proximal tubules. ${ }^{31-34}$ The concentration of oxalic acid in proximal tubules is usually high; proximal tubule cells are more sensitive than distal tubules and collecting duct cells, and are more vulnerable to crystallization or oxalic acid damage, which induces secretion of adhesion molecules. ${ }^{35}$ Under the same conditions, $\mathrm{CaOx}$ crystals can cause acute death of renal proximal tubule cells, but will not cause damage to collecting duct cells. ${ }^{36}$ The adhesion and aggregation behavior of crystals in the upstream proximal tubule will only be induced when the membrane fragments formed after the injury and secreted adhesion molecules are transferred to the distal end and collecting duct. Although lithogenesis occurs in the distal parts of the nephron and renal papillae, adhesion and aggregation are mainly caused by the transfer of adhesion molecules due to damage of the proximal tubules. ${ }^{37}$ Therefore, understanding the damage and adhesion behavior of proximal tubules is necessary. Moreover, the renal proximal tubule cell model is commonly applied in studies on oxalate toxicity and adhesion behavior. ${ }^{38-40}$

Evan et $\mathrm{al}^{41}$ proved that plaque originates in the basement membranes of the thin loops of Henle and spreads through the interstitium around the ducts of Bellini into the papillary epithelium. When the epithelium is disrupted, the calcium phosphate deposits are in contact with the supersaturated urine issued from the vicinal nephrons, thus promoting $\mathrm{CaOx}$ crystallization and crystal entrapment at the plaque surface. ${ }^{42,43}$ Thus, cell injury is a vital step to induce $\mathrm{CaOx}$ adhesion and aggregation.

UOx is generally more than $1.0 \mathrm{mM} /$ day in primary hyperoxalate urology, $0.5-1.0 \mathrm{mM} /$ day in enteric hyperoxaluria, and generally lower in common urological stone diseases. ${ }^{44}$ The concentration required for in vitro experiments may be higher, ranging from 2 to $4 \mathrm{mM} .^{1,45,46}$ For example. Mittal et $\mathrm{al}^{1}$ injured NRK-52E renal epithelial cells with $2 \mathrm{mM}$ sodium oxalate. Chen et al ${ }^{46}$ tested HK-2 cell viability with $1,2,3,5$, or $10 \mathrm{mM}$ oxalate and $200 \mu \mathrm{g} /$ $\mathrm{mL} \mathrm{COM}$ crystals for 4,12 , and $24 \mathrm{~h}$, and selected $2 \mathrm{mM}$ oxalate and $200 \mu \mathrm{g} / \mathrm{mL}$ COM crystals for proteomic analysis. Therefore, we simulated a high oxalic acid environment based on $2.8 \mathrm{mM}$ oxalate concentration.

The oxidative damage of cells caused by high oxalic acid and the effect of $\mathrm{CaOx}$ adhesion before and after cell repair were studied. The effect of hyperoxaluria (including hereditary and intestinal hyperoxaluria) on calculi was simulated. Hyperoxaluria is an autosomal recessive genetic disease. ${ }^{47}$ The metabolic disorder of the chromosome leads to the loss of glyoxylate metabolizing enzyme, and then to excessive production of endogenous oxalate, thus resulting in complications, such as renal calcinosis, recurrent renal calculi, and chronic kidney disease. ${ }^{48,49}$ The effect of hyperoxaluria on stone formation cannot be ignored.

\section{Crystal adhesion promotes formation of renal calculi}

Crystalluria is very common, but stone formation is not. Therefore, crystal retention is crucial to the formation of stones. ${ }^{50}$ The transit time for formed microcrystals in vivo to pass through the kidney is $5-10 \mathrm{~min}$, and the inner diameter of the renal tubular segment is $15-60 \mu \mathrm{m} .{ }^{51}$ Since $\mathrm{CaOx}$ crystals grow at a speed of $1-2 \mu \mathrm{m} / \mathrm{min}$ in urine, the 5-10 min transit time is too short for the crystals to nucleate and grow to a size sufficient to block tubules, and the crystals can be easily excreted in urine without causing stone formation. ${ }^{52}$ In other words, nonadherent crystals will not pose a great risk for the formation of kidney stones. Only crystals adhering to renal epithelial cells have sufficient time to grow on the cell surface or aggregate to form large crystals, eventually leading to the formation of kidney stones. ${ }^{53}$

$\mathrm{CaOx}$ adheres to Randall's plaque and grows on the surface; this process is an important mechanism for the formation of stones. However, there is currently no ideal cell model for building Randall's plaque. Given that the crystal properties of $\mathrm{CaOx}$ and $\mathrm{HAP}$ are similar, if a Randall plaque model is built by adding HAP, then interference between $\mathrm{CaOx}$ and $\mathrm{HAP}$ will inevitably occur in fluorescence colocalization and quantitative detection. Therefore, to differentiate the crystal adhesion between normal and damaged cells, we selected the currently accepted oxalic acid damage model and quantitatively analyzed the change in adhesion by fluorescence staining. It is also the more commonly used model of crystal adhesion. ${ }^{6,38}$

In studies concerning $\mathrm{CaOx}$ crystal adhesion cell, the most common concentrations used are between 100 and $200 \mu \mathrm{g} /$ $\mathrm{mL}{ }^{54-57}$ If the concentration is too small, $\mathrm{CaOx}$ crystals have no toxic effect on cells, while excessive concentration will lead to death of most cells, which is not conducive to subsequent adhesion research. For example, Narula et $\mathrm{al}^{57}$ 
applied $200 \mu \mathrm{g} / \mathrm{mL}$ COM to renal epithelial cells and Cao et $\mathrm{al}^{55}$ applied $200 \mu \mathrm{g} / \mathrm{mL}$ COM to ureter epithelial cells. Therefore, we chose $200 \mu \mathrm{g} / \mathrm{mL}$ for the current experiment.

Adhesion of calcium oxalate crystals to renal tubular epithelial cells is one of the key causes of kidney stone formation, ${ }^{52}$ and cell damage is an important factor of crystal-cell adhesion. Figure 9 displays the changes in crystal adhesion and biochemical indicators of HK-2 cells before and after tea polysaccharide repair. Decreased cell viability and increased ROS level indicate that HK-2 cells are severely damaged by oxalic acid, and cell damage promotes the expression of adherent molecules (such as PS and OPN) on the cell surface. These negatively charged adhesion molecules adsorb calcium ions in solution and adhere to the surface of the positively charged COM crystals. ${ }^{30}$ Our previous study has demonstrated that the adhesion of nano$\mathrm{COM}$ and calcium oxalate dihydrate crystals to cells is positively correlated with the degree of cell damage. $^{7}$

Polysaccharides can be adsorbed on the crystal surface, thereby avoiding the direct action of the crystal and the cell, reducing cell damage caused by the crystal, and reducing crystal adhesion. ${ }^{58,59}$ For example, Lieske et al ${ }^{58}$ showed that macromolecules, such as glycosaminoglycans (GAGs), can inhibit the adhesion of COM to BSC-1 cells by adsorbing on the surface of crystals. Verkoelen et $\mathrm{al}^{59}$ also demonstrated that natural mucopolysaccharides (GAGs) and semisynthetic polysaccharides pretreated with COM crystals inhibit the adhesion of crystals to the surface of MDCK cells. de Cógáin et $\mathrm{al}^{60}$ found that adding Arab cactus extract (which proves to be a polysaccharide) and COM crystals simultaneously into MDCK-1 cells decreases the amount of crystal adhesion. However, when the MDCK-1 cells are pretreated with this extract for 0.25 or $24 \mathrm{~h}$ before adding COM crystals, the amount of crystal adhesion does not change considerably. Thus, crystal adhesion is inhibited because the polysaccharide covers the crystal surface and changes the interaction between crystals and the cell receptor.

GAGs are important stone inhibitors in urine and contain acidic groups, such as sulfate $\left(-\mathrm{OSO}_{3}-\right)$ and/or carboxyl $(-\mathrm{COO}-)$, which are similar to plant polysaccharides in terms of molecular structure and physicochemical properties. Polysaccharides can inhibit the nucleation, growth, and aggregation of $\mathrm{CaOx}$ crystals, as well as the adhesion of crystals to renal epithelial cells, thereby hindering the formation of $\mathrm{CaOx}$ kidney stones. The inhibitory effect of polysaccharides on the growth of $\mathrm{CaOx}$ crystals is attributed to

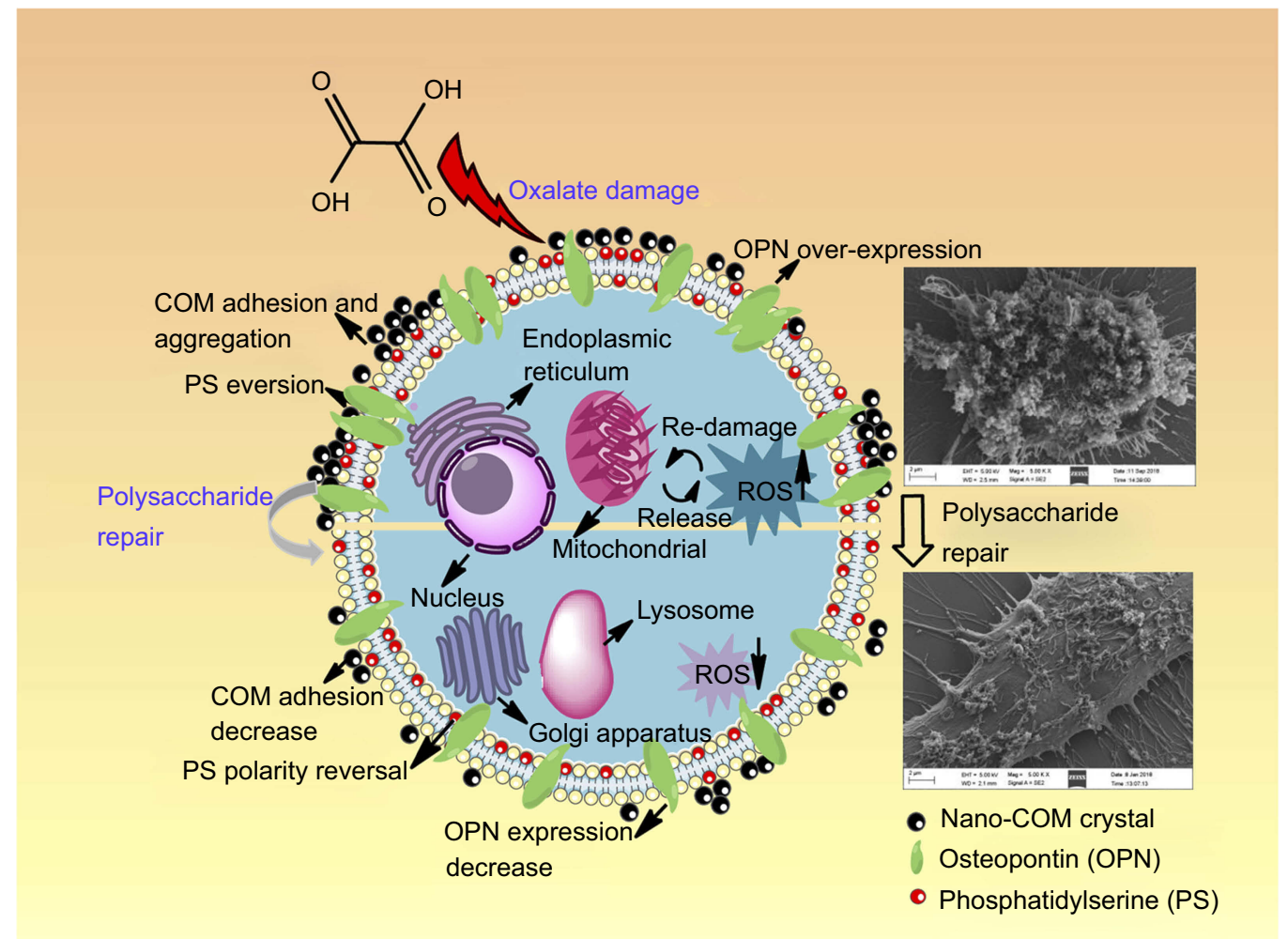

Figure 9 The changes of crystal adhesion and biochemical indicators of HK-2 cells before and after tea polysaccharide repair. Abbreviations: COM, calcium oxalate monohydrate; HK-2, human kidney proximal tubular epithelial; OPN, osteopontin; PS, phosphatidylserine; ROS, reactive oxygen species. 
the ability of the acidic groups of the polysaccharides to chelate the $\mathrm{Ca}^{2+}$ ions in the solution to form soluble complexes, reduce the supersaturation of the solution, and inhibit the formation of $\mathrm{CaOx}$ crystals. ${ }^{13,61}$ Tea polysaccharide is similar to GAGs in chemical structure, so it may be used to repair damaged renal epithelial cells and inhibit stone formation. $^{62}$

\section{Repair of damaged cells by polysaccharides}

In most literature on cell repair/protection, the applied polysaccharide concentration ranges from 25 to $200 \mu \mathrm{g} / \mathrm{mL}^{63-66}$ For example, Vasantharaja et $\mathrm{al}^{66}$ found that pretreatment of $25,50,75$, and $100 \mu \mathrm{g} / \mathrm{mL}$ brown algae Padina gymnospora sulfated polysaccharide significantly reduces $\mathrm{H}_{2} \mathrm{O}_{2}$-induced L-929 cell damage in a concentration-dependent manner. Cai et $\mathrm{al}^{63}$ showed that 50,100 , or $200 \mu \mathrm{g} / \mathrm{mL}$ oyster polysaccharides can reduce $\mathrm{H}_{2} \mathrm{O}_{2}$-induced intestinal epithelial (IEC6) cell apoptosis and oxidative damage through reduction of free radicals, thereby decreasing the secretion of proinflammatory factors and inhibiting the nuclear factor- $\kappa \mathrm{B}$ pathway. Moreover, in our previous study, ${ }^{62}$ the reparative effects of TPS0, TPS2, and TPS3 on damaged HK-2 cells were compared at concentrations of $20,40,60,80$, and $100 \mu \mathrm{g} / \mathrm{mL}$ (Figure 4B). The best reparative effect of all polysaccharides is observed at a concentration of $80 \mu \mathrm{g} / \mathrm{ml}$, and the effect is lower at other concentrations. Thus, we chose $80 \mu \mathrm{g} / \mathrm{mL}$ polysaccharides to repair cells.

Tea polysaccharides can repair damaged HK-2 cells by reducing ROS. ROS are a class of highly reactive small molecules that oxidize proteins, lipids, and DNA, leading to oxidative damage and programmed cell death. ${ }^{67} \mathrm{Li}$ et $\mathrm{al}^{68}$ revealed that Ganoderma atrum polysaccharide can reduce the ROS content induced by cyclophosphamide in the spleen and thymus of mice.

Negatively charged OPN molecules not only adsorb calcium ions in solution but also adhere to positively

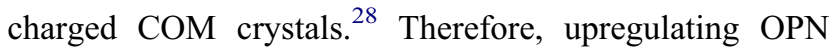
promotes crystal adhesion on the cell surface, ${ }^{69}$ thereby promoting kidney stone formation. The OPN expression of the repair group was between the normal and injury groups, implying that polysaccharide can repair damaged cells and reduce OPN expression, thereby reducing crystal adhesion to the cell surface.

Comparing the relationship between the percentage of cells adhering to crystals and cell viability, OPN expression, and PS eversion of the cell surface, the percentage was negatively correlated with cell viability (Figure $8 \mathrm{C}$ ), that is, the greater the cell viability, the stronger the anticrystal adhesion ability. However, the percentage of cells adhering to crystals was positively correlated with the amount of OPN expression (Figure 8D) and PS eversion (Figure 8E) on the cell surface, that is, the greater the amount of PS or OPN on the cell surface, the stronger the ability to adhere to crystals.

\section{Therapeutic potentials in treating kidney stones of tea polysaccharides}

The anti-stone effect of tea polysaccharides has attracted research attention. In vitro studies showed that tea polysaccharides can reduce the nucleation rate in solution and inhibit the growth of $\mathrm{CaOx}$ crystals. Our previous research showed that tea polysaccharides can inhibit the growth of $\mathrm{CaOx}$ crystal and increase the absolute value of zeta potential on the crystal surface, thus inhibiting crystal aggregation. $^{70}$ Mosta'anzade et $^{71}{ }^{71}$ showed that Alhaji herbal tea can prevent high concentrations of calcium and oxalate ions from forming $\mathrm{CaOx}$ crystals. Montealegre et $\mathrm{al}^{72}$ found that Blumea balsamifera (Sambong) tea can form a large number of easily negated small crystals by reducing the free energy of the crystal surface and the nucleation rate.

Many clinical trials have demonstrated the anti-stone effect of tea polysaccharides. For example, Rode et $\mathrm{al}^{73}$ found that drinking green tea significantly reduced the prevalence of COM stones in 273 high-calcium kidney stones. Shu et $\mathrm{al}^{74}$ surveyed the history of 319,211 Shanghai men $(n=58,054$; baseline age of $40-74$ years $)$ and 696,950 Shanghai women $(n=69,166$; baseline age of 40-70 years) tea intake information. The results showed that the intake of green tea was associated with a lower risk of developing kidney stones. Chen et $\mathrm{al}^{75}$ examined 13,842 subjects with kidney stones by ultrasound and found that the daily tea consumption of people with or without kidney stones is $119.2 \pm 306.8$ and 131.7 $\pm 347.3 \mathrm{~mL}$, respectively. Thus, daily tea intake of $\geq 240 \mathrm{~mL}$ (two cups) and tea consumption of $\geq 20$ cups can reduce the risk of kidney stone formation. Similar results were reported by Sihombing et al. ${ }^{76}$

After repair by tea polysaccharides with different molecular weights, the cell viability of damaged cells increased, the ROS level decreased, and PS and OPN expression was downregulated, resulting in a decrease in the number of adhered crystals. Mittal et $\mathrm{al}^{1}$ argued that 
Tris-Cl extract of Terminalia arjuna prevents cell injury in a dose-dependent manner when normal rat epithelialderived renal tubular epithelial cells (NRK-52E renal epithelial cells) are damaged by $2 \mathrm{mM}$ oxalic acid for 48 $\mathrm{h}$, increasing the cell viability and reducing $\mathrm{CaOx}$ crystal adhesion. Polysaccharide repair can significantly reduce crystal adhesion to cells, thereby decreasing the risk of kidney stone formation.

Our results show that TPS2 has great potential to repair damaged HK-2 cells. The reason is that if the molecular weight is too large, the polysaccharide does not easily function across the cell membrane. On the contrary, if the molecular weight is too small, the stereostructure of the polysaccharide is destroyed, and the biological activity is low. Other studies have similar findings. For example, $\mathrm{Xu}$ et $\mathrm{al}^{77}$ ultrafiltered four Camellia oleifera seed cake polysaccharides (COP-1, COP-2, COP-3, and COP-4) with molecular weight of $7.9,36,83$, and $225 \mathrm{kDa}$, respectively. Their antioxidant activity and reducing ability are COP-2 $>$ COPc $>$ COP $-3>$ COP $-4>$ COP -1 , that is, the ability of COP -2 with moderate molecular weight $(36 \mathrm{kDa})$ is the strongest.

Given that tea is the most popular nonalcoholic beverage and common food ingredient in Asia, ${ }^{78}$ tea polysaccharides extracted from green tea are nontoxic to humans. Tea polysaccharides, especially TPS-2, may be considered as candidate drugs with therapeutic potential for treating kidney stones. Studies with animal and clinical experiments are in progress.

\section{Conclusions}

Tea polysaccharides increase the viability of damaged HK2 cells, reduce the ROS level, and reduce PS and OPN expression on the cell surface, thereby decreasing COM crystals adherence to renal epithelial cells. The repair effect of tea polysaccharides is closely related to their molecular weight, and the polysaccharide with moderate molecular weight has the best repair effect. The results of the present study suggest that tea polysaccharides have great potential as candidate drugs for the prevention and treatment of kidney stones.

\section{Acknowledgment}

This research work was granted by the National Natural Science Foundation of China (NO. 21701050 and 81670644).

\section{Disclosure}

The authors report no conflicts of interest in this work.

\section{References}

1. Mittal A, Tandon S, Singla SK, Tandon C. In vitro inhibition of calcium oxalate crystallization and crystal adherence to renal tubular epithelial cells by Terminalia arjuna. Urolithiasis. 2016;44 (2):117-125. doi:10.1007/s00240-015-0822-0

2. Tiselius H-G. Should we modify the principles of risk evaluation and recurrence preventive treatment of patients with calcium oxalate stone disease in view of the etiologic importance of calcium phosphate? Urolithiasis. 2015;43(1):S47-S57. doi:10.1007/s00240014-0698-4

3. Manissorn J, Khamchun S, Vinaiphat A, Thongboonkerd V. Alphatubulin enhanced renal tubular cell proliferation and tissue repair but reduced cell death and cell-crystal adhesion. Sci Rep. 2016;6:28808. doi:10.1038/srep28808

4. Abd El-Salam M, Bastos JK, Han JJ, et al. The synthesized plant metabolite 3,4,5-Tri-O-Galloylquinic acid methyl ester inhibits calcium oxalate crystal growth in a drosophila model, downregulates renal cell surface annexin A1 expression, and decreases crystal adhesion to cells. J Med Chem. 2018;61(4):1609-1621. doi:10.1021/acs. jmedchem.7b01566

5. Semangoen T, Sinchaikul S, Chen S-T, Thongboonkerd V. Altered proteins in MDCK renal tubular cells in response to calcium oxalate dihydrate crystal adhesion: A proteomics approach. J Proteome Res. 2008;7(7):2889-2896. doi:10.1021/pr800113k

6. Wang B, Wu B, Liu J, et al. Analysis of altered MicroRNA expression profiles in proximal renal tubular cells in response to calcium oxalate monohydrate crystal adhesion: implications for kidney stone disease. PLoS One. 2014;9(7):e101306. doi:10.1371/journal. pone. 0101306

7. Gan Q-Z, Sun X-Y, Bhadja P, Yao X-Q, Ouyang J-M. Reinjury risk of nano-calcium oxalate monohydrate and calcium oxalate dihydrate crystals on injured renal epithelial cells: aggravation of crystal adhesion and aggregation. Int J Nanomed. 2016;11:2839-2854.

8. Li Y, Yu S, Gan X, et al. MRP-1 and BCRP promote the externalization of phosphatidylserine in oxalate-treated renal epithelial cells: implications for calcium oxalate urolithiasis. Urology. 2017; 107:271.e279-271.e217.

9. Asselman M, Verhulst A, Van Ballegooijen ES, Bangma $\mathrm{CH}$, Verkoelen CF, De Broe ME. Hyaluronan is apically secreted and expressed by proliferating or regenerating renal tubular cells. Kidney Int. 2005;68(1):71-83.

10. Verkoelen CF, Van Der Boom BG, Houtsmuller AB, Schroder FH, Romijn JC. Increased calcium oxalate monohydrate crystal binding to injured renal tubular epithelial cells in culture. Am J Physiol Renal Physiol. 1998;274(5):F958-F965. doi:10.1152/ajprenal.1998.274.5. F958

11. Gan Q-Z, Sun X-Y, Ouyang J-M. Adhesion and internalization differences of COM nanocrystals on vero cells before and after cell damage. Mater Sci Eng C Mater Biol Appl. 2016;59:286-295. doi:10.1016/j.msec.2015.10.012

12. Ma X-T, Sun X-Y, Yu K, Gui B-S, Gui Q, Ouyang J-M. Effect of content of sulfate groups in seaweed polysaccharides on antioxidant activity and repair effect of subcellular organelles in injured HK-2 cells. Oxid Med Cell Longev. 2017;2017:2542950. doi:10.1155/2017/ 2542950

13. Bhadja P, Lunagariya J, Ouyang J-M. Seaweed sulphated polysaccharide as an inhibitor of calcium oxalate renal stone formation. J Funct Foods. 2016;27:685-694. doi:10.1016/j.jff.2016.10.016

14. Sun X-Y, Ouyang J-M, Bhadja P, Gui Q, Peng H, Liu J. Protective effects of degraded soybean polysaccharides on renal epithelial cells exposed to oxidative damage. J Agric Food Chem. 2016;64 (42):7911-7920. doi:10.1021/acs.jafc.6b03323

15. Nie S-P, Xie M-Y. A review on the isolation and structure of tea polysaccharides and their bioactivities. Food Hydrocolloid. 2011;25 (2):144-149. doi:10.1016/j.foodhyd.2010.04.010 
16. Cao H. Polysaccharides from Chinese tea: recent advance on bioactivity and function. Int $J$ Biol Macromol. 2013;62:76-79. doi:10.1016/j.ijbiomac.2013.08.033

17. Xiao JB, Jiang H. A Review on the structure-function relationship aspect of polysaccharides from tea materials. Crit Rev Food Sci Nutr. 2015;55(7):930-938. doi:10.1080/10408398.2012.678423

18. He N, Shi X, Zhao Y, Tian L, Wang D, Yang X. Inhibitory effects and molecular mechanisms of selenium-containing tea polysaccharides on human breast cancer MCF-7 cells. J Agric Food Chem. 2013;61 (3):579-588. doi:10.1021/jf3036929

19. Gao Y, Zhou Y, Zhang Q, et al. Hydrothermal extraction, structural characterization, and inhibition HeLa cells proliferation of functional polysaccharides from Chinese tea Zhongcha 108. J Funct Foods. 2017;39:1-8. doi:10.1016/j.jff.2017.09.057

20. Park H-R, Hwang D, Suh H-J, Yu K-W, Kim TY, Shin K-S. Antitumor and antimetastatic activities of rhamnogalacturonan-IItype polysaccharide isolated from mature leaves of green tea via activation of macrophages and natural killer cells. Int $J$ Biol Macromol. 2017;99:179-186. doi:10.1016/j.ijbiomac.2017.02.043

21. Wang D, Zhao Y, Sun Y, Yang X. Protective effects of Ziyang tea polysaccharides on $\mathrm{CCl} 4$-induced oxidative liver damage in mice. Food Chem. 2014;143:371-378. doi:10.1016/j.foodchem.2013.08.005

22. Zhao W-H, Zhai H, Wang L, Shu L, Zhou L-H. The protective effects of tea polysaccharides on injury and apoptosis of mouse sertoly cells induced by glyphosate. Curr Top Nutraceut R. 2016;14(1):81-90.

23. Zhai X, Ren D, Luo Y, Hu Y, Yang X. Chemical characteristics of an Ilex Kuding tea polysaccharide and its protective effects against high fructose-induced liver injury and vascular endothelial dysfunction in mice. Food Funct. 2017;8(7):2536-2547. doi:10.1039/c7fo00490g

24. Chen X, Wang Y, Wu Y, et al. Green tea polysaccharide-conjugates protect human umbilical vein endothelial cells against impairments triggered by high glucose. Int J Biol Macromol. 2011;49(1):50-54. doi:10.1016/j.ijbiomac.2011.03.008

25. Wang J-M, Sun X-Y, Ouyang J-M. Structural characterization, antioxidant activity, and biomedical application of astragalus polysaccharide degradation products. Int J Polym Sci. 2018;2018:5136185. doi:10.1155/2018/5136185

26. X-Y S, J-M O, A-J L, Y-M D, Gan Q-Z. Preparation, characterization, and in vitro cytotoxicity of COM and COD crystals with various sizes. Mat Sci Eng C-Mater. 2015;57:147-156. doi:10.1016/j. msec.2015.07.032

27. Chaiyarit S, Mungdee S, Thongboonkerd V. Non-radioactive labelling of calcium oxalate crystals for investigations of crystal-cell interactions and internalization. Anal Methods-UK. 2010;2 (10):1536-1541. doi:10.1039/C0AY00321B

28. Ding Q, Yang D, Zhang W, et al. Antioxidant and anti-aging activities of the polysaccharide TLH-3 from Tricholoma lobayense. Int J Biol Macromol. 2016;85:133-140. doi:10.1016/j.ijbiomac.2015.12.058

29. Zhao Z, Johnson MS, Chen B, et al. Live-cell imaging to detect phosphatidylserine externalization in brain endothelial cells exposed to ionizing radiation: implications for the treatment of brain arteriovenous malformations. $J$ Neurosurg. 2016;124(6):1780-1787. doi: $10.3171 / 2015.4$.JNS142129

30. Evan AP, Coe FL, Rittling SR, et al. Apatite plaque particles in inner medulla of kidneys of calcium oxalate stone formers: osteopontin localization. Kidney Int. 2005;68(1):145-154. doi:10.1111/j.15231755.2005.00388.x

31. Oliver J, MacDowell M, Whang R, Welt LG. The renal lesions of electrolyte imbalance. IV. The intranephronic calculosis of experimental magnesium depletion. J Exp Med. 1966;124(2):263-278. doi:10.1084/jem.124.2.263

32. Khan SR, Hackett RL. Calcium oxalate urolithiasis in the rat: is it a model for human stone disease? A review of recent literature. Scan Electron Microsc. 1985;2:759-774.

33. Cifuentes Delatte L, Minon-Cifuentes J, Medina JA. New studies on papillary calculi. J Urol. 1987;137(5):1024-1029.
34. Khan SR, Hackett RL. Retention of calcium oxalate crystals in renal tubules. Scanning Microsc. 1991;5(3):707-711.

35. Thamilselvan S, Byer KJ, Hackett RL, Khan SR. Free radical scavengers, catalase and superoxide dismutase provide protection from oxalate-associated injury to LLC-PK1 and MDCK cells. J Urol. 2000;164(1):224-229.

36. Schepers MSJ, Ballegooijen ESV, Bangma CH, Verkoelen CF. Crystals cause acute necrotic cell death in renal proximal tubule cells, but not in collecting tubule cells. Kidney Int. 2005;68 (4):1543-1553. doi:10.1111/j.1523-1755.2005.00566.x

37. Yuen JWM, Gohel M-DI, Poon N-W, Shum DKY, Tam P-C, $\mathrm{Au}$ DWT. The initial and subsequent inflammatory events during calcium oxalate lithiasis. Clin Chim Acta. 2010;411(15-16):1018-1026. doi:10.1016/j.cca.2010.03.015

38. Hovda KE, Guo C, Austin R, McMartin KE. Renal toxicity of ethylene glycol results from internalization of calcium oxalate crystals by proximal tubule cells. Toxicol Lett. 2010;192(3):365-372.

39. Wang S, Du P, Zhang N, et al. Oligomeric proanthocyanidins protect against HK-2 cell injury induced by oxalate and calcium oxalate monohydrate crystals. Urolithiasis. 2016;44(3):203-210. doi:10.1007/s00240-015-0826-9

40. Convento MB, Pessoa EA, Cruz E, Da Gloria MA, Schor N, Borges FT. Calcium oxalate crystals and oxalate induce an epithelial-to-mesenchymal transition in the proximal tubular epithelial cells: contribution to oxalate kidney injury. Sci Rep. 2017;7:45740

41. Evan AP, Lingeman JE, Coe FL, et al. Randall's plaque of patients with nephrolithiasis begins in basement membranes of thin loops of Henle. J Clin Invest. 2003;111(5):607-616.

42. Evan AP, Coe FL, Lingeman JE, et al. Mechanism of formation of human calcium oxalate renal stones on Randall's plaque. Anat Rec. 2007;290(10):1315-1323. doi:10.1002/ar.20580

43. Daudon M, Bazin D, Letavernier E. Randall's plaque as the origin of calcium oxalate kidney stones. Urolithiasis. 2015;43(Suppl 1):5-11. doi:10.1007/s00240-014-0703-y

44. Hoppe B, Beck BB, Milliner DS. The primary hyperoxalurias. Kidney Int. 2009;75(12):1264-1271. doi:10.1038/ki.2009.32

45. Knoll T, Steidler A, Trojan L, et al. The influence of oxalate on renal epithelial and interstitial cells. Urol Res. 2004;32(4):304-309. doi:10.1007/s00240-004-0429-3

46. Chen S, Gao X, Sun Y, Xu C, Wang L, Zhou T. Analysis of HK-2 cells exposed to oxalate and calcium oxalate crystals: proteomic insights into the molecular mechanisms of renal injury and stone formation. Urol Res. 2010;38(1):7-15. doi:10.1007/s00240-009-0226-0

47. Dhondup T, Lorenz EC, Milliner DS, Lieske JC. Combined liver-kidney transplantation for primary hyperoxaluria type 2: a case report. Am J Transplant. 2018;18(1):253-257. doi:10.1111/ajt.14418

48. Zhao M, Xu D, Wu D, Whittaker JW, Terkeltaub R, Lu Y. Nanocapsules of oxalate oxidase for hyperoxaluria treatment. Nano Res. 2018;11(5):2682-2688. doi:10.1007/s12274-017-1898-3

49. Zabaleta N, Barberia M, Martin-Higueras C, et al. CRISPR/Cas9mediated glycolate oxidase disruption is an efficacious and safe treatment for primary hyperoxaluria type I. Nat Commun. 2018;9. doi10.1038/s41467-018-07827-1

50. Khan SR. Renal tubular damage/dysfunction: key to the formation of kidney stones. Urol Res. 2006;34(2):86-91. doi:10.1007/s00240-0050016-2

51. Khaskhali MH, Byer KJ, Khan SR. The effect of calcium on calcium oxalate monohydrate crystal-induced renal epithelial injury. Urol Res. 2009;37(1):1-6. doi:10.1007/s00240-008-0160-6

52. Tsujihata M. Mechanism of calcium oxalate renal stone formation and renal tubular cell injury. Int $J$ Urol. 2008;15(2):115-120. doi:10.1111/j.1442-2042.2007.01953.x

53. Escobar C, Byer KJ, Khaskheli H, Khan SR. Apatite induced renal epithelial injury: insight into the pathogenesis of kidney stones. J Urol. 2008;180(1):379-387. doi:10.1016/j.juro.2008.02.041 
54. Vinaiphat A, Aluksanasuwan S, Manissorn J, Sutthimethakorn S, Thongboonkerd V. Response of renal tubular cells to differential types and doses of calcium oxalate crystals: integrative proteome network analysis and functional investigations. Proteomics. 2017;17:15-16.

55. Cao Z, Zhao J, Yang K. Cu-bearing stainless steel reduces cytotoxicity and crystals adhesion after ureteral epithelial cells exposing to calcium oxalate monohydrate. Sci Rep. 2018;8:14094. doi:10.1038/ s41598-018-32388-0

56. Fong-Ngern K, Vinaiphat A, Thongboonkerd V. Microvillar injury in renal tubular epithelial cells induced by calcium oxalate crystal and the protective role of epigallocatechin-3-gallate. Faseb J. 2017;31 (1):120-131. doi:10.1096/fj.201600543R

57. Narula S, Tandon S, Singh SK, Tandon C. Kidney stone matrix proteins ameliorate calcium oxalate monohydrate induced apoptotic injury to renal epithelial cells. Life Sci. 2016;164:23-30. doi:10.1016/ j.lfs.2016.08.026

58. Lieske JC, Leonard R, Toback FG. Adhesion of calcium oxalate monohydrate crystals to renal epithelial cells is inhibited by specific anions. Am J Physiol. 1995;268(4 Pt 2):F604-F612. doi:10.1152/ ajprenal.1995.268.4.F604

59. Verkoelen CF, Romijn JC, Cao LC, Boeve ER, De Bruijn WC, Schroder FH. Crystal-cell interaction inhibition by polysaccharides. J Urol. 1996;155(2):749-752.

60. de Cógáin MR, Linnes MP, Lee HJ, et al. Aqueous extract of Costus arabicus inhibits calcium oxalate crystal growth and adhesion to renal epithelial cells. Urolithiasis. 2015;43(2):119-124. doi:10.1007/ s00240-015-0749-5

61. Poon NW, Gohel MDI. Urinary glycosaminoglycans and glycoproteins in a calcium oxalate crystallization system. Carbohydr Res. 2012;347(1):64-68. doi:10.1016/j.carres.2011.09.022

62. Sun X-Y, Wang J-M, Ouyang J-M, Kuang L. Antioxidant activities and repair effects on oxidatively damaged HK-2 cells of tea polysaccharides with different molecular weights. Oxid Med Cell Longev. 2018;2018:5297539.

63. Cai B, Wan P, Chen H, et al. Composition characterization of oyster polysaccharides from Crassostrea hongkongensis and their protective effect against H2O2-induced oxidative damage in IEC-6 cells. Int $J$ Biol Macromol. 2019;124:246-254. doi:10.1016/j. ijbiomac.2018.11.154

64. Chu Q, Chen M, Song D, et al. Apios americana Medik flowers polysaccharide (AFP-2) attenuates $\mathrm{H} 2 \mathrm{O} 2$ induced neurotoxicity in PC12 cells. Int $J$ Biol Macromol. 2019;123:1115-1124. doi:10.1016/j.ijbiomac.2018.11.078

65. Guo Q, Xu L, Chen Y, et al. Structural characterization of corn silk polysaccharides and its effect in $\mathrm{H} 2 \mathrm{O} 2$ induced oxidative damage in L6 skeletal muscle cells. Carbohydr Polym. 2019;208:161-167. doi:10.1016/j.carbpol.2018.12.049
66. Vasantharaja R, Abraham LS, Gopinath V, Hariharan D, Smita KM. Attenuation of oxidative stress induced mitochondrial dysfunction and cytotoxicity in fibroblast cells by sulfated polysaccharide from Padina gymnospora. Int $J$ Biol Macromol. 2019;124:50-59. doi:10.1016/j.ijbiomac.2018.11.104

67. Li Z, Xu X, Leng X, et al. Roles of reactive oxygen species in cell signaling pathways and immune responses to viral infections. Arch Virol. 2017;162(3):603-610. doi:10.1007/s00705-016-3130-2

68. Li W-J, Li L, Zhen W-Y, et al. Ganoderma atrum polysaccharide ameliorates ROS generation and apoptosis in spleen and thymus of immunosuppressed mice. Food Chem Toxicol. 2017;99:199-208. doi:10.1016/j.fct.2016.11.033

69. Mandal T, Shtukenberg AG, Yu AC, Zhong X, Ward MD. Effect of urinary macromolecules on L-cystine crystal growth and crystal surface adhesion. Cryst Growth Des. 2016;16(1):423-431. doi:10.1021/acs. cgd.5b01413

70. Huang F, Sun X-Y, Ouyang J-M. Effects of Tea Polysaccharide on Crystallization of Calcium Oxalate. DEStech Trans Biol Health. 2018;25486(icmsb):530-535.

71. Mosta'anzade H, Honarmand E, Khalilian M, Mozafari A. Prevention and treatment of calcium oxalate kidney stones using Alhaji herbal tea. Avicenna J Phytomed. 2015;5:107-108.

72. Montealegre CM, De Leon RL. Blumea balsamifera (Sambong) tea as a therapeutic drink for calcium oxalate stones. MATEC Web Conf. 2016;62:02002. doi:10.1051/matecconf/20166202002

73. Rode J, Bazin D, Dessombz A, et al. Daily green tea infusions in hypercalciuric renal stone patients: no evidence for increased stone risk factors or oxalate-dependent stones. Nutrients. 2019;11(2):256. doi: $10.3390 /$ nu 11020256

74. Shu X, Cai H, Xiang Y-B, et al. Green tea intake and risk of incident kidney stones: prospective cohort studies in middle-aged and elderly Chinese individuals. Int J Urol. 2019;26(2):241-246. doi:10.1111/ iju.13849

75. Chen H-Y, Wu J-S, Chang Y-F, et al. Increased amount and duration of tea consumption may be associated with decreased risk of renal stone disease. World J Urol. 2019;37(2):379-384. doi:10.1007/ s00345-018-2394-4

76. Sihombing AT, Adi S, Partogu B. Influence of coffee, tea and drinking water source on calcium kidney stone disease in universitas padjdjaran/hasan sadikin hospital bandung west java indonesia: a case control study. Open Access Lib J. 2017;4(07):e3798.

77. Xu Z, Li X, Feng S, et al. Characteristics and bioactivities of different molecular weight polysaccharides from camellia seed cake. Int J Biol Macromol. 2016;91:1025-1032.

78. Chen G, Yuan Q, Saeeduddin M, Ou S, Zeng X, Ye H. Recent advances in tea polysaccharides: extraction, purification, physicochemical characterization and bioactivities. Carbohydr Polym. 2016;153:663-678.

\section{Publish your work in this journal}

The International Journal of Nanomedicine is an international, peerreviewed journal focusing on the application of nanotechnology in diagnostics, therapeutics, and drug delivery systems throughout the biomedical field. This journal is indexed on PubMed Central, MedLine, CAS, SciSearch ${ }^{\mathbb{}}$, Current Contents ${ }^{\mathbb{R}} /$ Clinical Medicine,
Journal Citation Reports/Science Edition, EMBase, Scopus and the Elsevier Bibliographic databases. The manuscript management system is completely online and includes a very quick and fair peer-review system, which is all easy to use. Visit http://www.dovepress.com testimonials.php to read real quotes from published authors. 